\title{
Evaluation of poultry manure, cattle dung, water and cattle urine-based composts on soil chemical properties, growth and yield of Amaranthus cruentus L.
}

\author{
F. A. OLOWOKERE* \& B. AKINBINU \\ (F.A.O. \& B.A.: Department of Soil Science and Land Management, Federal Univer- \\ sity of Agriculture, Abeokuta 110001, Ogun-State, Nigeria) \\ *Corresponding author's email: olowokerefa@funaab.edu.ng
}

\begin{abstract}
The inclusion of cattle urine in compost preparation will improve compost quality, particularly with respect to nutrient composition. Field experiments were conducted at the organic farm of the Federal University of Agriculture, Abeokuta, Ogun State in 2014 and 2016 to evaluate the effects of water and cattle urine composts, sole poultry manure and cattle dung on post-harvest soil properties, growth and yield of Amaranthus cruentus. Treatments used were: compost derived from poultry manure + rice husk with water as source of moisture at 2.5, 5.0, 6.5 and $7.5 \mathrm{tha}^{-1}$, (PRW2.5, PRW5, PRW6.5 and PRW7.5 respectively), compost derived from poultry manure + rice husk with cattle urine as source of moisture at 2.5, 5.0, 5.4 and $7.5 \mathrm{t} \mathrm{ha}^{-1}$ (PRU2.5, PRW5, PRW5.4 and PRW7.5 respectively) and control. Post-harvest soil was analyzed for chemical properties, agronomic parameters and yield of Amaranthus cruentus were evaluated. Results showed that the application of PRU5.4 resulted in highest values for most of the agronomic parameters in both years, while the competition for highest values of post-harvest soil parameters was between PRW5 and PRW6.5. The highest values of Amaranthus cruentus yield in both years resulted from the application of PRU5.4 and PM3.
\end{abstract}

Keywords: Cattle urine; compost; poultry manure; cattle dung; rice husk Original scientific paper. Received 02 Aug 2019; revised 09 Feb 2021

\section{Introduction}

Tropical soils have been described to be highly weathered, low in nitrogen and organic matter (Obi \& Ekperigin, 2001; Ayeni, 2011). This has resulted in nutritionally poor soils leading to reduced productivity and difficulty in both subsistence and commercial agriculture. Kostov (2016) observed that one of the main processes causing soil degradation is soil organic matter depletion. Decline in organic matter content of soil was reported by Ewulo
(2005) to affect not only crop yield, but the physical and chemical properties of the soil. In order to improve the nutritionally poor status of tropical soils, chemical fertilizer application came into the limelight. However, usage of chemical fertilizer was reported to have resulted in poor crop yield, low soil organic matter content and acidity (Milosevic \& Milosevic 2009; Ayeni, 2011). In addition to these are non-availability, adulteration, high-cost implication and water pollution (Serpil, 2012;

Ghana Jnl Agric. Sci. 56 (1), $65-78$

GJAS is an Open Access Journal and distributed under the terms of the Creative Commons (CC) License [CC BY 4.0] 
Chude, 2006). The fertility of the soil can be improved by maintenance of its organic matter content, this is said to be possible through the use of organic-based fertilizer (Olowoake \& Ojo 2014). Organic-based fertilizers are amendments derived from plant and animal remains such as poultry manure, cow dung and rice husk.

Management of solid waste has been said to be a serious problem in most developing nations (Wegedie, 2018). Composting is a method that can be used to effectively manage solid waste, Aina \& Adewole, (2017) described composting as a simple and environmentally friendly clean-up technology to improve soil properties and crop yield while composting is said to be the reduction of large volumes of organic materials rapidly through biological process (Geisel \& Unruh, 2007). Compost is defined by Gurtler et al. (2018) as an organic material that has been degraded into a nutrientstabilized humus-like substance through intense microbial activity, which can provide essential plant nutrients to aid crop growth. Compost has been listed among the available resources and management that can be used for reclamation of degraded soil for nutrient recovery and recycling and increase in crop productivity (McGeehan, 2012). Compost contains high organic carbon content but low nitrogen content (El-Sayed \& Khaler, 2015) and the low nitrogen content has been a limitation to the use of compost.

Cattle urine is a liquid waste that is rich in nitrogen, the high $\mathrm{N}$ concentration in cattle urine has been linked to nitrate leaching from agricultural soils (Selbie et al., 2015) due to indiscriminate deposition on soil in patches. Averagely, the volume of urine excreted per cattle is 2.1 liters daily (Selbie et al., 2015), while Saxena and Sewak (2016) reported that
India has about 190 million dairy cattle in 2012, and each cattle was reported to excrete about five liters of urine daily. About 13.9 million cattle were reported by Lawal - Adebowale (2012) to be reared in Nigeria.

Adequate availability of cattle urine is evidenced by the large quantity produced in different countries on a daily or annual basis, for example, NPCS Board of Consultants and Engineers (2008) reported that annual production of urine from bovine in India was approximately 370 million tones. In Nigeria, if the population of cattle reared as reported by Adebowale-Lawal (2012) (13.9 million) is multiplied by the average volume of urine excreted per cattle (2.1 million) as reported by Selbie et al. (2015), this means that about 29.19 million liters of cattle urine are produced daily. Singh (2017) also reported that over 5,000 liters of cow urine were produced daily in Pantajali. Cow urine has also been reported to be sold in some London shops (Sejal, 2016). All these facts show that cattle urine is abundantly produced in different countries, it is as a result of the abundance of cattle urine that Choudhany et al. (2017) described its use in agriculture as low-cost agricultural practice by farmers. Efforts have not been made towards the collection of cow urine because the awareness of its usefulness particularly in agriculture is still very low, as a result of the low awareness of proper utilization of cattle urine, the huge amount excreted in various countries are becoming a waste that is difficult to manage thereby affecting the environment. Therefore, to avoid the negative effect of indiscriminate deposition of cattle urine on our soils, this could be channeled towards composting.

Compost quality and stability are dependent on the composition of the raw material used for the composting process 
(Ranalli et al., 2001). Therefore, the quality of composts can be improved by using raw materials with high plant nutrients. According to Lin et al. (2008) and Kuwahara et al. (2009), moisture content is described as one of the most important factors responsible for biological reactions within a compost pile, moisture content of a compost pile should be about $50 \%$ (Liang et al., 2003). Excess moisture will trigger anaerobic conditions while inadequate moisture will limit microbial activity (Das \& Keener, 1997). Generally, water has been used as a source of moisture during composting (Aya et al., 2015), however, we hypothesized that if cattle urine which is rich in nitrogen (Choudhary et al., 2017) is used as a source of moisture, this may probably improve the quality of the compost apart from performing moisturizing role.

The objectives of this research work were to evaluate the effect of compost derived from rice husk moistened with water and compost derived from poultry manure and rice husk moistened with cattle urine, sole poultry manure and sole cattle dung on soil chemical properties, growth and yield of Amaranthus cruentus L.

\section{Materials and Methods}

\section{Description of the Experimental Site}

The experiment was conducted at the organic farm of the Federal University of Agriculture, Abeokuta $\left(97.12^{\circ} \mathrm{N}\right.$ and $\left.7.20^{\circ} \mathrm{E}\right)$ Nigeria. The site is located in the transition zone of subhumid forest and the derived savannah. The area is characterized by distinct wet and dry seasons (bimodal rainfall distribution) with the wet season between April and October and the dry season between November and March. The mean annual rainfall in the area is about 1400 $\mathrm{mm}$ and mean annual temperature is about $22.2^{\circ} \mathrm{C}$. The soil in the area is described as Oxic Paleustalf (FDALR 1990). The chemical and selected physical properties of the soil used for the experiment are shown in Table 1. Information on temperature and rainfall pattern is shown in Table 2.

TABLE 1

Chemical and physical properties of soil used for the experiment

\begin{tabular}{ll}
\hline \multicolumn{1}{c}{ Property } & Value \\
\hline $\mathrm{pH}\left(\mathrm{H}_{2} \mathrm{O}\right)$ & 6.8 \\
Avail. $\mathrm{P}\left(\mathrm{mg} \mathrm{kg}^{-1}\right)$ & 13.77 \\
& \\
$\mathrm{TN}\left(\mathrm{g} \mathrm{kg}^{-1}\right)$ & 1.2 \\
$\mathrm{OC}\left(\mathrm{g} \mathrm{kg}^{-1}\right)$ & 4.6 \\
Exch. K $\left(\mathrm{cmol} \mathrm{kg}^{-1}\right)$ & 0.68 \\
Exch. Ca $\left(\mathrm{cmol} \mathrm{kg}^{-1}\right)$ & 0.23 \\
Exch. Mg $\left(\mathrm{cmol} \mathrm{kg}^{-1}\right)$ & 0.20 \\
Sand $\left(\mathrm{g} \mathrm{kg}^{-1}\right)$ & 862 \\
Silt $\left(\mathrm{g} \mathrm{kg}^{-1}\right)$ & 120 \\
Clay $\left(\mathrm{g} \mathrm{kg}^{-1}\right)$ & 18 \\
Textural class & Sandy loam \\
\hline
\end{tabular}

TABLE 2

Mean temperature and rainfall pattern for 2014 and 2016

\begin{tabular}{lllll}
\hline & \multicolumn{2}{c}{2014} & \multicolumn{2}{c}{2016} \\
Month & $\begin{array}{l}\text { Mean } \\
\text { Tem- } \\
\text { perature } \\
\left({ }^{\circ} \mathrm{C}\right)\end{array}$ & $\begin{array}{c}\text { Total } \\
\text { rainfall } \\
(\mathrm{mm})\end{array}$ & $\begin{array}{c}\text { Mean } \\
\text { Tempera- } \\
\text { ture }\left({ }^{\circ} \mathrm{C}\right)\end{array}$ & $\begin{array}{l}\text { Total } \\
\text { rain- } \\
\text { fall } \\
(\mathrm{mm})\end{array}$ \\
\hline January & 28.9 & 8.2 & 28.1 & 32.0 \\
February & 29.3 & 15.5 & 30.3 & 6.0 \\
March & 28.8 & 149.1 & 29.5 & 150.3 \\
April & 28.2 & 87.2 & 29.2 & 68.2 \\
May & 27.8 & 113.8 & 29.0 & 226.2 \\
June & 27.5 & 116.5 & 26.7 & 150.3 \\
July & 26.6 & 90.7 & 26.3 & 65.2 \\
August & 25.6 & 92.7 & 25.7 & 63.6 \\
September & 26.3 & 160.8 & 26.9 & 229.0 \\
October & 26.3 & 205.9 & 27.6 & 155.4 \\
November & 27.5 & 17.6 & 28.0 & 5.9 \\
December & 28.5 & 0.0 & 22.5 & 0.0 \\
\hline S
\end{tabular}

Source: Department of Water Resources and Agricultural Meteorology, Federal University of Agriculture, Abeokuta Nigeria 


\section{Compost preparation}

Compost was made using rice husk and poultry manure at ratio $3: 1$, two heaps of compost materials were prepared, one was moistened with 50 liters of water while the second one was moistened with the same quantity of cattle urine. These were covered with black polythene sheets for heat generation and to prevent excess water from getting into the compost pile. These were allowed to decompose for twelve weeks while each pile was turned at two weeks intervals with the addition of cattle urine or water as the case may be.

\section{Poultry manure, cattle dung and cattle urine}

Poultry manure, cattle dung and urine were sourced from the college of animal science and livestock production (COLANIM) farm of the Federal University of Agriculture, Abeokuta, Nigeria. Poultry manure was obtained from layers pen under intensive system while cattle dung and urine were from cattle raised under semi-intensive system. Poultry manure and cattle dung were left for six weeks after collection before application. The chemical properties of the amendments are given in Table 3.

\section{Land clearing and plot demarcation}

The experimental area measuring $34 \mathrm{~m} \times 13 \mathrm{~m}$ was manually cleared and plots measuring 2 $\mathrm{m} \times 3 \mathrm{~m}$ were demarcated. Plots and replicates were spaced by a distance of $1 \mathrm{~m}$. Vegetable beds were manually constructed on the plots.

\section{Pre-planting soil sampling}

Soil samples $(0-15 \mathrm{~cm}$ layer) were collected randomly from six points on the experimental area, these were bulked and sub-sampled for routine analysis.

\section{Treatment application}

The optimum nitrogen requirement of $67.5 \mathrm{~kg}$ $\mathrm{ha}^{-1}$ for Amaranthus cruentus as recommended by Makinde (2013), native soil $\mathrm{N}$ and $\mathrm{N}$ content of organic materials were used as a guide to determine the rates of organic materials used. The following treatments were applied: compost rates equivalent to $67 \mathrm{~kg} \mathrm{~N}$ $\mathrm{ha}^{-1}$ : compost derived from poultry manure + rice husk with water as source of moisture at $6.5 \mathrm{t} \mathrm{ha}^{-1}$ (PRW 6.5), compost derived from poultry manure + rice husk with cattle urine as source of moisture at $5.4 \mathrm{t} \mathrm{ha}^{-1}$ (PRU 5.4), two lower rates of each type of compost (PRW 2.5, PRW 5.0, PRU 2.5, PRU 5) and one higher rate of each type of compost (PRW 7.5 and PRU 7.5), sole poultry manure and cattle manure equivalent to $67.5 \mathrm{~kg} \mathrm{~N} \mathrm{ha}^{-1}$, (PM3 and CD 5.3 respectively) and control. Treatments were applied by broadcasting and incorporated into the top soil on May 22, 2014 and June 1, 2016. Treatments were laid out using randomized complete block design and replicated three times. The experimental site was left without planting any crop at the end of the experiment in 2014 till the commencement of the 2016 trial. The experiment was carried out on the same plot in both years.

TABLE 3

Chemical properties of organic materials used for the experiment

\begin{tabular}{lcccccc}
\hline Property & $P R W$ & $P R U$ & $P M$ & $C D$ & \multicolumn{1}{c}{$R H$} & $C U$ \\
\hline $\mathrm{pH}\left(\mathrm{H}_{2} \mathrm{O}\right)$ & 7.65 & 8.24 & 7.30 & 9.60 & 6.80 & 80 \\
$\mathrm{OC}\left(\mathrm{g} \mathrm{kg}^{-1}\right)$ & 32.2 & 40.7 & 64.2 & 37.6 & 17.4 & 6.5 \\
$\mathrm{~N}\left(\mathrm{~g} \mathrm{~kg}^{-1}\right)$ & 10.4 & 12.5 & 22.4 & 12.8 & 5.9 & 8.2 \\
$\mathrm{P}\left(\mathrm{mg} \mathrm{kg}^{-1}\right)$ & 12.68 & 16.14 & 7.89 & 1.78 & 1.14 & 1.34 \\
$\mathrm{~K}\left(\mathrm{~g} \mathrm{~kg}^{-1}\right)$ & 8.60 & 10.22 & 1.61 & 1.14 & 4.11 & 1.02 \\
$\mathrm{Na}\left(\mathrm{g} \mathrm{kg}^{-1}\right)$ & 6.02 & 6.17 & 3.10 & 2.25 & 1.92 & 2.03 \\
$\mathrm{Ca}\left(\mathrm{g} \mathrm{kg}^{-1}\right)$ & 25.10 & 27.6 & 4.12 & 3.47 & 0.87 & 2.36 \\
$\mathrm{Mg}\left(\mathrm{g} \mathrm{kg}^{-1}\right)$ & 5.60 & 6.80 & 7.66 & 1.36 & 1.04 & 1.26 \\
$\mathrm{C} / \mathrm{N}$ & 3.09 & 3.26 & 2.87 & 2.94 & 2.95 & 3.23 \\
\hline
\end{tabular}

KEY

PRW - Compost derived from poultry manure + rice husk +water 
PRU - Compost derived from poultry manure + rice husk + cattle urine

PM - Poultry manure

CD - Cattle dung

$\mathrm{RH}$ - Rice husk

$\mathrm{CU}$ - Cattle urine

\section{Planting and crop management}

Amaranthus cruentus L. seeds obtained from the National Horticultural Research Institute, Idi-Ishin, Ibadan Oyo State, Nigeria were planted at $30 \mathrm{~cm}$ by $50 \mathrm{~cm}$ spacing two weeks after amendment application in 2014. Seedlings were thinned to one plant per stand at 10 days after sowing, making a plant population of 140,000 plants per hectare. Weeds were controlled manually at four weeks after planting.

In 2016, the plots used for the trial in 2014 were cleared manually, treatments were applied by broadcasting method and incorporated in the $0-15 \mathrm{~cm}$ soil layer. The plots were left for two weeks before planting the test crop (Amaranthus cruentus). The seeds obtained from the same source as in 2014 were planted at $30 \mathrm{~cm}$ by $50 \mathrm{~cm}$ spacing two weeks after amendment application. Seedlings were thinned to one plant per stand at ten days after sowing. Weeds were controlled manually at four weeks after planting.

\section{Data collection}

Post-harvest soil sampling

At the end of the experiment in each year (2014 and 2016), soil samples $(0-15 \mathrm{~cm})$ were collected from four points on each plot, bulked and sub-sampled for analysis.

\section{Soil Preparation and analysis}

Soil samples were air-dried for two weeks, crushed with the aid of porcelain mortar and pestle, sieved with $2 \mathrm{~mm}$ and $0.5 \mathrm{~mm}$ sieves. Soil sieved with a $2 \mathrm{~mm}$ sieve was used for the determination of $\mathrm{pH}, \mathrm{P}, \mathrm{K}, \mathrm{Ca}$ and $\mathrm{Mg}$ while one sieved with a $0.5 \mathrm{~mm}$ sieve was used for the determination of TN and OC.

Soil $\mathrm{pH}$ was determined by glass electrode method (Mclean, 1982), phosphorus by Bray 1 method (Bray \& Kurtz, 1945), potassium by flame photometry while calcium and magnesium were determined by atomic absorption spectrometry. Particle size was by hydrometer method (Bouyoucos, 1962). Nitrogen was determined by Kjeldahl method (Bremner, 1996) and organic carbon by wet oxidation method (Nelson \& Sommers, 1996).

\section{Agronomic parameters}

Six plants were randomly selected from the middle row of each plot and the following parameters were determined at five weeks after planting: plant height which was determined with the aid of a graduated ruler, number of leaves by physical counting and stem girth using a Vernier caliper.

\section{Fresh yield}

Amaranthus cruentus L. was harvested by uprooting at five weeks after sowing, soil particles attached to the roots were carefully removed, after which they were weighed on a scale.

\section{Amendment Analysis}

Amendments used for the experiment were analyzed for $\mathrm{pH}$ by glass electrode method, nitrogen by Kjeldahl method, phosphorus by vanado-molybdate method (Aduayi \& Gatitu, 1973), potassium by flame photometry, calcium and magnesium by atomic absorption method and organic carbon by wet oxidation method. 


\section{Statistical analysis}

Data were subjected to the analysis of variance using the statistical analysis system (SAS) 2003 package. Significant means were separated using the Least Significant Difference at 5\% probability level.

\section{Results and discussion}

Post-harvest soil chemical properties

Post-harvest soil $\mathrm{pH}$ ranged between 6.45 and 7.40 in 2014. Plots with the application of PRU5.4 had the highest $\mathrm{pH}$ value (7.40) followed by PRU2.5 (7.30) while the lowest (6.45) was from the control plot. The $\mathrm{pH}$ of all amended plots was significantly $(\mathrm{p}<0.05)$ higher than the control. Application of PRU5.4 was also observed to have significantly $(\mathrm{p}<$ 0.05 ) increased post-harvest soil $\mathrm{pH}$ above PRW2.5, PRW5, PRW6.5, PRW7.5, CD5.3 and PM3. A similar trend was observed in the year 2016 where all the $\mathrm{pH}$ of the soil from amended plots were significantly $(\mathrm{p}<$ 0.05 ) higher than the control plot. The highest $\mathrm{pH}$ (7.53) was however recorded on the plot amended with PRW5 which was followed by PRW7.5 (7.36). The pH values of all amended plots were statistically similar (Table 4).

Amendment application significantly $(p<0.05)$ increased the organic carbon content of post-harvest soil in both years. In year 2014, the order of increase in organic carbon content was: PRU7.5 > PRW6.5, PRW2.5, PRU5.4, PM3 > CD5.3, PRU5, PRU2.5, PRW7.5 > control, while in 2016, the order was: PRW6.5 $>$ CD5.3 > PM3 > PRU5 > PRW7.5, PRU5.4, PRU7.5 > PRW5 $>$ PRW2.5 $>$ C. The organic carbon contents of all the amended plots were not significantly different from each other in both years. Total nitrogen was significantly ( $\mathrm{p}<$ 0.05 ) increased in comparison with the control by amendment application in both years. The highest value $\left(0.2 \mathrm{~g} \mathrm{~kg}^{-1}\right)$ was observed on PRW6.5 and PRU5.4 amended plots in 2014, while the highest value $\left(0.13 \mathrm{~g} \mathrm{~kg}^{-1}\right)$ was from PRW6.5, CD5.3 and PM3 in 2016. Phosphorus content of post-harvest soil ranged between $12.66 \mathrm{mg} \mathrm{kg}^{-1}$ and $15.62 \mathrm{mg} \mathrm{kg}^{-1}$ in the first year (2014). All amendments with the exception of PRW6.5 gave significantly $(p<0.05)$ higher $P$ content than the control. Percentage increase over the control by the various treatments are: PRW5 (18.95), PRW7.5 (18.64), CD5.3 (17.95), PRU2.5 (15.94), PM3 (15.88), PRU5 (15.54), PRW2.5, PRU7.5, (14.69), PRU5.4 (13.58), PRW6.5 (10.97). P values in 2016 were statistically similar but were significantly $(\mathrm{p}<0.05)$ higher in 2016 than in 2014.

TABLE 4

Chemical properties of post- harvest soil as affected by poultry manure, cattle dung, water and cattle urine based composts in 2014 and 2016

\begin{tabular}{|c|c|c|c|c|c|c|c|c|}
\hline Treatment & Year & $p H$ & $\begin{array}{l}O C \\
\left(g \mathrm{~kg}^{l}\right)\end{array}$ & $\begin{array}{l}T N \\
\left(g \mathrm{~kg}^{-l}\right)\end{array}$ & $\begin{array}{l}\text { Avail P } \\
{\left.k g^{-1}\right)}^{(m g}\end{array}$ & K & $\mathrm{Ca}$ & $\begin{array}{c}\mathrm{Mg} \\
\mathrm{cmol} \mathrm{kg}{ }^{-1}\end{array}$ \\
\hline Control & 2014 & 6.45 & 4.0 & 1.3 & 12.66 & 0.65 & 0.21 & 0.22 \\
\hline PM3 & & 7.20 & 5.7 & 1.9 & 15.05 & 0.80 & 0.25 & 0.27 \\
\hline CD5.3 & & 7.20 & 5.5 & 1.9 & 15.43 & 0.78 & 0.25 & 0.27 \\
\hline PRU2.5 & & 7.30 & 5.5 & 1.8 & 15.06 & 0.79 & 0.25 & 0.26 \\
\hline PRU5 & & 7.25 & 5.5 & 1.9 & 14.99 & 0.79 & 0.25 & 0.28 \\
\hline PRU5.4 & & 7.40 & 5.7 & 2.0 & 14.65 & 0.79 & 0.26 & 0.27 \\
\hline PRU7.5 & & 7.25 & 5.9 & 1.9 & 14.84 & 0.81 & 0.26 & 0.28 \\
\hline PRW2.5 & & 7.10 & 5.8 & 1.9 & 14.84 & 0.73 & 0.25 & 0.25 \\
\hline PRW5 & & 7.20 & 5.6 & 1.9 & 15.62 & 0.82 & 0.25 & 0.26 \\
\hline PRW6.5 & & 7.20 & 5.8 & 2.0 & 14.22 & 0.82 & 0.25 & 0.28 \\
\hline PRW7.5 & & 7.20 & 5.5 & 1.8 & 15.56 & 0.81 & 0.25 & 0.27 \\
\hline Control & 2016 & 6.55 & 5.4 & 0.5 & 8.65 & 0.54 & 0.17 & 0.12 \\
\hline PM3 & & 7.24 & 14.2 & 1.3 & 21.70 & 0.71 & 0.19 & 0.19 \\
\hline CD5.3 & & 7.25 & 14.3 & 1.3 & 17.60 & 0.72 & 0.22 & 0.18 \\
\hline PRU2.5 & & 7.15 & 13.7 & 1.1 & 21.50 & 0.69 & 0.23 & 0.17 \\
\hline PRU5 & & 7.14 & 14.1 & 1.2 & 25.05 & 0.72 & 0.24 & 0.20 \\
\hline PRU5.4 & & 7.31 & 13.2 & 1.1 & 21.95 & 0.70 & 0.20 & 0.19 \\
\hline PRU7.5 & & 7.29 & 13.2 & 1.1 & 21.30 & 0.74 & 0.29 & 0.23 \\
\hline PRW2.5 & & 7.20 & 11.9 & 1.0 & 21.85 & 0.76 & 0.25 & 0.19 \\
\hline PRW5 & & 7.53 & 12.9 & 1.1 & 24.40 & 0.78 & 0.25 & 0.21 \\
\hline PRW6.5 & & 7.30 & 15.0 & 1.3 & 24.50 & 0.77 & 0.18 & 0.21 \\
\hline
\end{tabular}




\begin{tabular}{lccccccc} 
PRW7.5 & 7.36 & 13.2 & 1.1 & 27.10 & 0.75 & 0.30 & 0.24 \\
LSD (p<0.05) & & & & & & & \\
2014 & 0.16 & 1.2 & 0.5 & 1.74 & 0.04 & 0.02 & 2.20 \\
2016 & 0.47 & 6.2 & 0.4 & NS & 0.19 & 0.08 & 0.06 \\
Treatment*Year & NS & 0.9 & 0.1 & 5.96 & 0.04 & 0.02 & 0.12 \\
\hline
\end{tabular}

PRW - Compost derived from poultry manure + rice husk +water

PRU - Compost derived from poultry manure + rice husk + cattle urine

PM - Poultry manure

CD - Cattle dung

The potassium content of all amended plots was significantly $(\mathrm{p}<0.05)$ higher than the control in 2014. The highest value $\left(0.82 \mathrm{cmol} \mathrm{kg}^{-1}\right)$ was however observed on PRW5 and PRW6.5 treated plots. Potassium content of plots amended with PRW2.5 was significantly $(\mathrm{p}<$ 0.05) lower than PRW5, PRW6.5 and PRW7.5 while $\mathrm{K}$ values of all plots amended with PRU were similar and significantly $(\mathrm{p}<0.05)$ higher than PRW2.5. In 2016, all PRW amended plots gave significantly $(\mathrm{p}<0.05)$ higher $\mathrm{K}$ content over the control while only PRU7.5 treated plot out of all the plots amended with PRU was significantly higher than control. The highest value $\left(0.78 \mathrm{cmol} \mathrm{kg}^{-1}\right)$ was observed on PRW5 treated plot. Potassium was significantly higher in 2014 than in 2016 (Table 4).

$$
\text { Application of amendment }
$$
significantly $(p<0.05)$ increased the soil calcium content, the range was between 0.21 cmol kg-1 and $0.26 \mathrm{cmol} \mathrm{kg}^{-1}$, where the highest value was recorded on plots amended with PRU5.4 and PRU7.5 in 2014. Application of PRW2.5, PRW5, PRW7.5 and PRU7.5 significantly $(\mathrm{p}<0.05)$ increased the calcium content in 2016 . The highest value $(0.30 \mathrm{cmol}$ $\left.\mathrm{kg}^{-1}\right)$ was from PRW7.5 amended plots while the lowest $\left(0.17 \mathrm{cmol} \mathrm{kg}^{-1}\right)$ was from the control plot. Calcium content was significantly higher in 2014 than in 2016 (Table 4).
Magnesium was significantly $(\mathrm{p}<$ 0.05 ) greater than the control by amendment application in 2014. The highest percentage increase over the control (21.43) was observed on plots treated with PRW6.5, PRU5 and PRU7.5. The least Mg content was from an un-amended plot. The magnesium content of PRU7.5 treated plot was significantly ( $\mathrm{p}$ $<0.05$ ) higher than PRW2.5 plot but was similar to other treatments in 2014. Treatment application with the exception of PRU2.5 and CD5.3 significantly $(\mathrm{p}<0.05)$ increased the magnesium content over the control in 2016. Highest value $\left(0.24 \mathrm{cmol} \mathrm{kg}^{-1}\right)$ was observed on plots amended with PRW7.5 followed by PRU7.5 $\left(0.23 \mathrm{cmol} \mathrm{kg}^{-1}\right)$. Magnesium content of plots amended with PRW7.5 was significantly higher than PRU2.5 and CD5.3. $\mathrm{Mg}$ was significantly higher $(\mathrm{p}<0.05)$ in 2014 than in 2016.

Post-harvest soil $\mathrm{pH}$ was significantly greater than control in both years, this might have resulted from the organic nature of the amendments. Organic amendments were reported to be good sources of $\mathrm{CaCO}_{3}$ (Eghball, 1999). Application of organic amendment was reported by Han et al. (2016) to have increased the $\mathrm{pH}$ of soil under yellow poplar. The $\mathrm{pH}$ was highest in PRU5.4 and PRW5 in 2014 and 2016 respectively, the composts have higher calcium content than other amendments used for the study. The presence of calcium ion in the soil was reported by Darell (2012) to reduce soil acidity. Application of all amendments resulted in significantly greater $\mathrm{OC}$ in both years, the organic nature of the amendments could be the reason for this observation. Organic amendment application was reported by Huag et al. (2014) and Ma et al. (2011) to have increased the organic carbon content of a paddy field. 
Nitrogen was observed in this experiment to be greater in all amended plots, this could be due to low $\mathrm{N}$ losses under organic farming as reported by Knudsen et al. (2006). This observation is similar to that of Angelova et al. (2013) who reported an increase in the $\mathrm{N}$ content of soils treated with organic amendments. Potassium was greater than control with PRW application, this could also be due to low leaching of potassium from the soil, compost application was reported by Tong et al. (2018) to have resulted in high soil $\mathrm{K}$ content. A similar trend was observed for calcium and magnesium which were highest in plots amended with compost in both years, composts used for this study have higher calcium contents than PM and CD. Composts are reported to be rich in calcium and magnesium contents (Suvitha \& Remesh, 2017). PRW and PRU have higher $\mathrm{C} / \mathrm{N}$ ratio than $\mathrm{CD}$ and $\mathrm{PM}$ used for this study, therefore, high $\mathrm{Ca}$ and $\mathrm{Mg}$ in soils amended with the composts could have resulted from the gradual release of nutrients by the composts (Gershuny, 2001). Calcium, magnesium and potassium were lower in the soil in the second year of the study (2016) than in 2014, this could be explained by higher rainfall in the month (June) of most active growth of the crop in 2016, thereby reducing evaporation. This observation is similar to the findings of Austin and Vitousek (1998); QuintoMosquera and Moreno-Hurtado (2016) who reported significant reductions in exchangeable $\mathrm{K}$, $\mathrm{Ca}$ and $\mathrm{Mg}$ concentrations in the soil with increase in rainfall.

\section{Agronomic Parameters}

The height of Amaranthus cruentus increased significantly $(p<0.05)$ than the control with the application of organic amendments irrespective of whether compost, poultry manure or cattle dung in the first year (2014). The tallest plants $(21.43 \mathrm{~cm})$ were the ones amended with PRU5.4, the percentage increase over the control was $54.55 \%$. The height of Amaranthus cruentus was significantly ( $p<$ 0.05) increased above PRW2.5 and PRW7.5 with the application of PRU5.4 (Table 5). However, in 2016, only plants treated with PRU5.4 and PRW7.5 were significantly $(\mathrm{p}<$ $0.05)$ taller than the control. Plants amended with PRU5.4 were 51.48\% taller while ones with PRW7.5 were $42.15 \%$ taller than the control, it could also be observed that plants amended with PRU5.4 grew significantly (p $<0.05)$ taller than ones amended with PM3, PRU5, PRU7.5, PRW2.5, PRW5 and PRW6.5

Number of leaves of Amaranthus cruentus ranged from 7.29 to 18.53 in 2014, plants amended with PM3 had the highest number of leaves (18.53) followed by PRU5.4 (15.53), PRU7.5 (14.56), all the above values were significantly $(\mathrm{p}<0.05)$ higher than the control which had the lowest value (7.29). Application of PM3 significantly ( $p<0.05)$ increased the number of leaves of Amaranthus cruentus above CD5.3 but was however similar to those of other treatments. In 2016, only plants amended with CD5.3 and PRU5.4 had significantly ( $p<$ 0.05 ) higher number of leaves when compared with the control. The number of leaves of plants amended with CD5.3 were significantly ( $\mathrm{p}<$ 0.05) more than PRW5 and PRW6.5 treated plants. The stem girth of Amaranthus cruentus was between $2.53 \mathrm{~mm}$ and $4.92 \mathrm{~mm}$ in 2014, application of PM3 and PRU5.4 resulted in a significantly $(p<0.05)$ higher stem girth than the control, the percentage increase over the control was 48.58 and 43.27 respectively. In 2016, the application of PRU5.4 was observed to give significantly $(\mathrm{p}<0.05)$ higher stem girth than the control. Application of the above 
resulted in $48.44 \%$ increase in stem girth over the control. Stem girth was significantly higher in 2016 than in 2014 (Table 5).

It was observed that the application of PRU5.4 resulted in significantly taller plants, the number of leaves and stem girth than the control in both years, this could have resulted from higher nitrogen and phosphorus contents in PRU than PRW. Nitrogen and phosphorus were reported to increase the growth of Acer mono and garlic (Razaq et al., 2017; Betewulign \& Solomon, 2014). Increase in height of Amaranthus cruentus in 2014 and stem girth in 2016 by the application of PRU5.4 could be explained by the fact that this treatment supplied the equivalent amount of N $(67.5 \mathrm{~kg}$ $\mathrm{ha}^{-1}$ ) recommended for Amaranthus cruentus production (Makinde, 2013). The application of nitrogen was reported by Direkvandi et al. (2008) to improve the vegetative growth of tomatoes. The number of leaves resulting from the application of PM3 was the highest, this could be due to high N content in PM. Similar findings have been reported by Shormin and Kibria (2018).

Muhammad et al. (2004) also observed that nitrogen increased the number of leaves on Zinnia elegans $\mathrm{Cv}$. Meteor. The observed significant increase in the number of leaves of Amaranth plants amended with PM3 over CD5.3 could be due to higher N content in PM than CD. Dehariya et al. (2019) reported an increase in the number of leaves of Amaranthus tricolor $\mathrm{L}$. as a result of $\mathrm{N}$ application. High phosphorus content in PRU5.4 and PM3 could be responsible for significantly higher stem girth of Amaranthus cruentus over the control which resulted from the application of the above. This is similar to the findings of Zhu et al. (2017) who reported an increase in stem girth of tomato as a result of $\mathrm{P}$ application.

\section{Yield}

Application of all amendments resulted in significantly $(\mathrm{p}<0.05)$ higher Amaranthus cruentus yield than control in both years. In 2014, yield ranged from $0.76 \mathrm{tha}^{-1}$ and $3.76 \mathrm{t} \mathrm{ha}^{-}$ ${ }^{1}$, the highest yield which increased by $79.79 \%$ more than the control was from plants amended with PM3, followed by this was PRU7.5 which increased by $76.54 \%$ more than control. Application of PM3 resulted in significantly $(\mathrm{p}<0.05)$ higher yield than PRW2.5, PRW6.5 and PRW7.5. A similar trend was observed in 2016 where the application of all amendments significantly $(\mathrm{p}<0.05)$ increased the yield of Amaranthus cruentus over the control. The highest percentage increase (87.97) over the control resulted from the application of PRU5.4. The order was: PRU5.4 (87.97\%) > PM3 $(87.46 \%)>$ PRU2.5 $(86.99 \%)>$ CD5.3 $(86.94 \%)>$ PRW7.5 (86.48\%) $>$ PRW5 $(85.82 \%)>$ PRW $2.5(85.38 \%)>$ PRU5 $(85.10 \%)>$ PRW6.5 (84.43\%) > PRU7.5 $(83.97 \%)>$ Control (Figure 1). Significant increase in yield by all amendments could be due to the organic nature of the amendments. Organic amendments were reported by Gongwen et al. (2018), Wortman et al. (2017) and Maltas et al. (2018) to increase crop yield. The Highest Amaranthus yield observed in PM3 and PRU5.4 in 2014 and 2016 respectively could have resulted from high organic matter contents of the amendments. The stem girth of Amaranthus cruentus was significantly ( $\mathrm{p}<$ 0.05 ) higher in 2016 than 2014, this could be due to lower rainfall during the experimental period in 2014 (Table 2). Increased irrigation was reported by Kwizera et al. (2018) to increase the stem girth of Amaranth. 
TABLE 5

Height, number of leaves and stem girth of Amaranthus cruentus as affected by poultry manure, cattle dung, water and cow urine - based composts in 2014 and 2016

\begin{tabular}{|c|c|c|c|c|c|}
\hline Treatment & Year & $\begin{array}{l}\text { Height } \\
(\mathrm{cm})^{-n^{2}}\end{array}$ & $\begin{array}{l}\text { Number } \\
\text { leaves }\end{array}$ & $\begin{array}{l}\text { Stem } \\
(\mathrm{mm})\end{array}$ & girth \\
\hline Control & 2014 & 9.74 & 7.29 & & 2.53 \\
\hline PM3 & & 19.36 & 18.53 & & 4.92 \\
\hline CD5.3 & & 18.66 & 10.90 & & 3.81 \\
\hline PRU2.5 & & 18.14 & 12.69 & & 3.87 \\
\hline PRU5 & & 16.65 & 12.70 & & 3.34 \\
\hline PRU5.4 & & 21.43 & 15.53 & & 4.46 \\
\hline PRU7.5 & & 19.00 & 14.56 & & 3.35 \\
\hline PRW2.5 & & 15.15 & 12.69 & & 2.96 \\
\hline PRW5 & & 18.22 & 14.16 & & 4.12 \\
\hline PRW6.5 & & 16.16 & 12.76 & & 2.97 \\
\hline PRW7.5 & & 15.75 & 12.50 & & 3.58 \\
\hline Control & 2016 & 11.02 & 7.90 & & 3.47 \\
\hline PM3 & & 13.03 & 10.60 & & 4.69 \\
\hline CD5.3 & & 17.14 & 15.67 & & 5.11 \\
\hline PRU2.5 & & 16.13 & 12.47 & & 4.79 \\
\hline PRU5 & & 13.91 & 10.80 & & 4.10 \\
\hline PRU5.4 & & 22.71 & 15.00 & & 6.73 \\
\hline PRU7.5 & & 14.57 & 11.33 & & 3.88 \\
\hline PRW2.5 & & 15.26 & 12.40 & & 4.07 \\
\hline PRW5 & & 14.75 & 11.40 & & 4.97 \\
\hline PRW6.5 & & 15.43 & 9.20 & & 3.91 \\
\hline $\begin{array}{l}\text { PRW7.5 } \\
\mathrm{L} \quad \mathrm{S} \quad \mathrm{D} \\
(\mathrm{p}<0.05)\end{array}$ & & 19.05 & 12.40 & & 5.97 \\
\hline 2014 & & 4.99 & 6.48 & & 2.09 \\
\hline 2015 & & 6.67 & 6.17 & & 2.94 \\
\hline $\begin{array}{l}\text { Treatment*- } \\
\text { Year }\end{array}$ & & NS & NS & & 0.62 \\
\hline
\end{tabular}

\section{KEY}

PRW - Compost derived from poultry manure + rice husk + water

PRU - Compost derived from poultry manure + rice husk + cattle urine

PM - Poultry manure

$\mathrm{CD}$ - Cattle dung

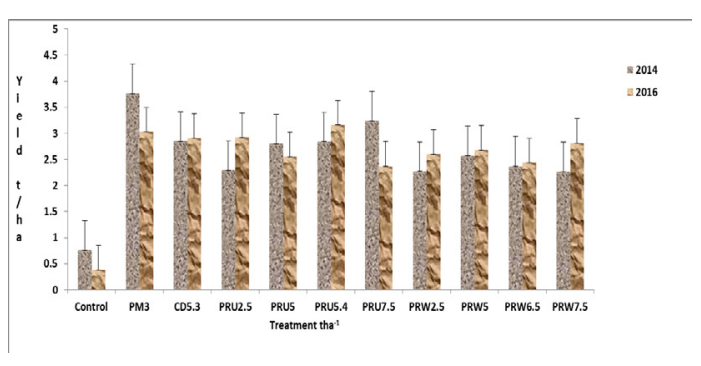

Fig. 1: Yield of Amaranthus cruentus as affected by poultry manure, cattle dung, water and cow urine based composts in 2014 and 2016

KEY

PRW - Compost derived from poultry manure + rice husk + water

PRU - Compost derived from poultry manure + rice husk + cattle urine

PM - Poultry manure

$\mathrm{CD}-$ Cattle dung

\section{Conclusion}

Results of this experiment showed that the application of PRU5.4 resulted in the highest values for most of the agronomic parameters in both years, while the competition for the highest values of post-harvest soil parameters was between PRW5 and PRW6.5. The highest values of Amaranthus cruentus yield in both years resulted from the application of PRU5.4 and PM3. Compost derived from Poultry manure + rice husk and moistened with cattle urine performed better than compost derived from poultry manure + rice husk and moistened with water, PM and CD in terms of growth and yield of Amaranthus cruentus. However, compost derived from poultry manure + rice husk moistened with water is more suitable for improving soil chemical properties under $A m a-$ ranthus cruentus.

Amaranthus cruentus could therefore be planted with compost derived from poultry 
manure + rice husk with cattle urine as a source of moisture at $5.4 \mathrm{t} \mathrm{ha}^{-1}$ (PRU5.4) for higher growth and yield while compost derived from poultry manure and rice husk with water as a source of moisture at 5.0 or $6.5 \mathrm{t} \mathrm{ha}^{-1}$ (PRW5 or PRW6.5) is suitable for improved soil chemical properties on similar soils.

\section{REFERENCES}

Aduayi, E. A. \& Gatitu, G. M. (1973) Routine soil and leaf analysis advisory service for coffee growers at coffee research station. Kenya Coffee 38, $278-281$.

Aina, B. M. \& Adewole, M. B. (2017) Comparative Assessment of the Growth and Yield of Two Drought-Tolerant varieties to Cow dung and Poultry Composts as soil Amendments. African Journal of Environmental Health Sciences 4, $93-102$.

Angelova, V. R., Akova, V. I., Artinova, N. S. \& Ivanov, K. I. (2013) The effect of organic amendments on soil chemical characteristics. Bulgarian Journal of Agricultural Science 19 (5), $958-971$.

Austin, A. T. \& Vitousek, P. M. (1998) Nutrient dynamics on a precipitation gradient in Hawaii. Oecologia 113 (4), 519 - 529. Doi: 10.1007/ s004420050405.

Aya, E. Z., Hamdy, S. \& Essam, G. (2015) Moisture content and thermal balance during composting of fish, banana mulch \& municipal solid wastes. European Scientific Journal 11 (5), $169-187$

Ayeni, L. S. (2011) Integrated Plant Nutrition Management. A Panacea for Sustainable crop Production in Nigeria. International Journal of Soil Science 6, 19 - 24.

Betewulign, E. A. \& Solomon, T. T. (2014) Evaluating the Role of Nitrogen and Phosphorus on the Growth Performance of Garlic (Allum sativum L.). Asian Journal of Agricultural Research 8, $211-217$.
Bouyoucos, G. J. (1962) Hydrometer method improved for making particle size analysis of soils. Agronomy Journal 54, 464 - 465.

Bray, R. H. \& Kurtz, L. T. (1945) Determination of total, organic, and available forms of phosphorus in soils. Soil Science 59, 39 - 45.

Bremner, J. M. (1996) Chapter 37 - Nitrogen - Total: In Methods of Soil Analysis. Part 3. Chemical Methods. SSSA Book Series no. 5.

Choudhary, S. Kushwaha, M., Preeti, S. S. \& Kumar, S. (2017) Cow Urine: A Boom for Sustainable Agriculture. International Journal of Current Microbiology and Applied Sciences 6 (2), 1824 - 1829. Doi: 10.20546/ijcmas.2017.602.205

Chude, V. (2006) Fertilizer situation in Nigeria. Paper presented by Alhaji Bello Sule, Director Fertilizer Department to the Program Advisory Committee on Agriculture and Food Security on 6 September, 2006. Abuja, Nigeria.

Darell, S. (2012) Calcium Basics. Farm Journal Conservation and Machinery, https://www.agweb. com

Das, K \& Keener, H. M. (1997) Moisture effect on Compaction and permeability in Composts. Journal of Environmental Engineering 123, $275-281$.

Dehariya, P., Mishra, D. K., Dhakad, R. \& Kumar, A. (2019) Studies of Different levels of Nitrogen Application on Growth and Yield of Amaranthus tricolor L. International Journal of Current Microbiology and Applied Sciences 8 (4), $1423-1427$.

Direkvandi, S. N., Ansari, N. A. \& Dehcordie, F. S. (2008) Effect of Different levels of Nitrogen Fertilizer with two types of Bio-Fertilizers on Growth and Yield of Two cultivars of Tomato (Lycopersicon esculentum Mill). Asian Journal of Plant Sciences 7 (8), 757 - 761. DOI: 10.392.3/ajps.2008.757761. 
Eghball, B. (1999) Liming effects of beef cattle feedlot manure on compost. Communications in Soil Science and Plant Analysis 30, 2563 - 2570. Doi: 10.1080/00103629909370396.

Khaler, E.G. (2015) Some physical and chemical properties of compost. International Journal of Waste resources 5, p. 172. Doi: 10.4172/22525211.1000172.

Ewulo, B. (2005) Effect of Poultry Dung and cattle Manure on Chemical Properties of Clay and Sandy Clay loam Soil. Journal of Animal and Veterinary Advances 4 (10), 839 - 841.

Federal Department of Agricultural Land Resources (FDALR). (1990) Soil map of Nigeria project: soil of Ogun-State, p. 148.

Geisel, P. M. \& Unruh, C. L. (2007) Compost in A Hurry. $8037^{\text {th }}$ edition. Regents of the University of California, Division of Agriculture and natural Resources.

Gershuny, G. (2001) Nourishing the Earth that Nourishes Us: How Compost Builds the Soil. Gardening How-to Articles. Brooklyn botanical Garden. https://www.bbg.org, assessed on 14/01/2019.

Gongwen, L., Ling, L., Ville-Petri F., Junjie, G., Shiwei, G., Quirong, S. \& Ning, L. (2018) Organic amendments increase crop yields by improving microbe-mediated soil functioning of agroecosystems: A meta-analysis. Soil Biology and Biochemistry 124, 105 - 115.

Gurtler, J. B., Doyle, M. P., Erickson, M. P., Jiang, X., Millner, P. \& Sharm, M. (2018) Composting to Inactivate Food borne Pathogens for Crop Soil Application. A Review. Journal of Food Protection 81 (11), 1821 - 1837. https:// doi.org/10.4315/0362-028X.JFP-18-217.

Han, S. H., An, J. Y., Hwang, J., Klim, S. B. \& Park, B. B. (2016) The effects of organic manure and chemical fertilizer on the growth and nutrient concentrations of yellow poplar (Liridendron tulipifera Lin.) in a nursery system. Forest Science and Technology 12 (3), 137 - 143, doi: 10.1080/21580103.2015.1135827.

Huag, Q., Li, D., Liu, K., Yu, X., Ye, H., Hu, H., Xu, X., Wang, S., Zhou, L., Duan, Y. \& Zhang, W. (2014) Effects of Long-Term Organic Amendments on Soil Organic Carbon in a Paddy Field: A Case Study on red soil. Journal of Integrative Agriculture 13 (3), 570 - 576. https://doi.org/10.1016/s20953119(13)60714-5.

Knudsen, M. T., Kristensen,I. S., Berntsen, J., Petersen, B. M. \& Kristensen, E. S. (2006) Estimated $\mathrm{N}$ leaching losses for organic and conventional farming in Denmark. The Journal of Agricultural Science 144, 135 - 149.

Kostov, O. S. (2016) Tropical Soils: Importance, Research and Management. Uttar Agriculture Science Journal 2 (3), 22 - 29.

Kuwahara, F., Sano, Y., Nakayama, A., Nakasaki, K. \& Fukazawa, T. (2009) Numerical modeling of a composting process with aeration. Journal of Porous Media 12 (10), 927 - 938.

Kwizera, C., Basil, TO, Niyonzima, H., Ntunzwenimana, M. \& Bucumi E. (2018) Effects of Different Irrigation Rates on Growth and Yield Parameters of Amaranth. International Journal of Advances in Scientific Research and Engineering 4 (9), 93 - 99. DOI:10.31695/ IJASRE.2018.32870.

Liang, C., Das, K. C. \& McClendon, R. W. (2003) The influence of temperature and moisture content regimes on the aerobic microbial activity of a biosolids composting blend. Bioresource Technology 86, $131-137$.

Lawal-Adebowale, O. A. (2012) "Dynamics of ruminant livestock management in the context of the Nigerian agricultural system', Livestock production, $61-80$. http://doi.org/10.5772/52923. 
Lin, Y. P., Huang, G. H., Lu, H. W. \& He, L. (2008) Modelling of substrate degradation and oxygen consumption in waste composting process. Waste Management 28, 1375 - 1385.

Ma, L., Yang, L. Z., Xia, L. Z., Shen, M. X., Yin, S. X. \& Li, Y. D. (2011) Long-term effects of inorganic and organic amendments on organic carbon in a paddy soil of the Taihu Lake region. China Pedosphere 21 (2), 186 - 196.

McGeehan, S. (2012) Impact of Waste Materials and Organic Amendments on Soil Properties and Vegetative Performance. Applied and Environmental Soil Science, 1687 - 7667.

Mclean, E. O. (1982) Soil pH and lime requirement. In: Methods of soil Analysis, $2^{\text {nd }}$ ed., Part 2, A. L. Page, R. H. Miller, and D. R. Keeney (eds.) Agronomy Monograph, 9, Madison, WI: American Society of Agronomy, 595 - 624.

Makinde, E. A. (2013) Nitrogen requirements of Amaranthus cruentus L. on Two Soil Types in Lagos State of Nigeria. Greener Journal of Educational Research 3 (1), 034 - 038. ISSN: 2276-7789

Maltas, A., Kebli, H., Oberholzer, H. R., Weisskopf, P. \& Sinaj, S. (2018) The effects of organic and mineral fertilizers on carbon sequestration, soil properties and crop yields from a longterm field experiment under a Swiss conventional farming system. Land Degradation \& Development 29 (4), https://doi.org/10.1002/ 1dr.2913.

Millosevic, T. \& Millosevic, N. (2009) Effect of zeolite, organic and inorganic fertilizers on soil chemical properties, growth and biomass yield of apple trees. Plant and soil Environment $\mathbf{5 5}$ (12), $528-535$.

Muhammad, A. K., Khurram, Z. \& Iftikar, A. (2004) Influence of Nitrogen on Growth and Flowering of Zinnia elegans cv. Meteor. Asian Journal of Plant Sciences 3, 571 - 573.
Nelson, D. W. \& Sommers, L. E. (1996) Total carbon, organic carbon and organic matter. P. 961 - 1010. In: Black, C. A., ed. Methods of soil analysis. Part 3. Chemical methods. Soil Science of America and American Society of Agronomy, Madison, WI, USA.

NIIR Project Consultancy Service Board of Consultants and Engineers (NPCS) (2008) The Complete Book on Organic Farming and Production of Organic Compost. Published by Asia Pacific Business Press Inc. p. 48.

Obi, O. \& Ekperigin, J. (2001) Effect of wastes and soil $\mathrm{pH}$ on growth and grain yield of crops. African Soils 32, 3 - 15.

Olowoake, A. A. \& Ojo, J. A. (2014) Effect of Fertilizer Types on the Growth and Yield of Amaranthus caudatus in Ilorin, Southern Guinea Savanna Zone of Nigeria. Advances in Agriculture 2014, Article ID 947062.

Quinto-Mosquera, H. \& Moreno-Hurtado, F. (2016) Precipitation effects on soil characteristics in tropical rain forests of the Chocó biogeographical region. Revista Facultad Nacional de Agronomía Medellín 69 (1), 7813 - 7823. http://dx.doi.org/10.15446/rfna.v69nl.54749.

Ranalli, G., Bottura, G., Taddei, P., Garavani, M., Marchetti, R. \& Sorlini, C. (2001) Composting of solid and sludge residues from Agricultural and Food Industries. Bioindicators of Monitoring and Compost Maturity. Journal of Environmental Science and Health, Part A, 36 (4), 415 - 436. DOI:10.1081/ESE-100103473.

Razaq, M., Zhang, P., Shen, H. I. \& Salahuddin. (2017) Influence of nitrogen and phosphorus on the growth and root morphology of Acer mono. PLoS ONE 12 (2), e 0171321 doi: 10.1371/journal.pone.0171321.

SAS (2003) Statistical Analysis System. SAS Release 9.1 for windows, SAS Institute Inc. Cary,NC, USA 
Saxena, K. L. \& Sewak, R. (2016) Livestock waste and its impact on human health. International Journal of Agricultural Sciences 6 (7), 1084 $-1099$.

Sejal, A. (2016) Cow urine sold alongside food in London shops. BBC News, England, 10 March 2016.https://www.bbc.com/news/uk-england-london-35749269. Assessed on $18^{\text {th }}$ June, 2020.

Selbie, D. R., Buckthought, L. E. \& Shepherd, M. A. (2015) The challenge of the Urine Patch for Managing Nitrogen in Grazed Pasture systems. Advances in Agronomy 129, 229 - 292.

Serpil, S. (2012) Investigation of Effect of Chemical Fertilizers on Environment. APCBEE Procedia 1, 287 - 292. https://doi.org 10.1016/j.apcbee.2012.03.047.

Shormin, T. \& Kibria, M. G. (2018) Effects of Nitrogen from Different Inorganic Fertilizers on Growth and Yield of Indian Spinach (Basella alba L.). IOSR Journal of Pharmacy and Biological Sciences 13 (5), 43 - 48. www.iosrjournals.org

Singh, R. (2017) We produce over 5000 liters of cow urine every day. Acharya Balkrishna, CEO, Patanjali. The Economic Times/ Panache. economictimes.indiantimes.com/ we-produce-over-5000-liters-of-cow-urineevery-day-acharya-balkrishna-ceo-patanjali/ articleshow/57015689.cms. Assessed on $18^{\text {th }}$ January, 2021.
Suvitha, K. \& Ramesh Babu, N. G. (2017) Nutritional Analysis of Various Composts for Agriculture Purposes. Imperial Journal of Interdisciplinary Research 3 (1), 45 - 48.

Tong, J., Sun, X., Li, S., Que, B. \& Wan, L. (2018) Reutilization of Green Waste as Compost for soil Improvement in the Afforested Land of the Beijing Plain. Sustainability 10, p. 2376. doi:10.3390/su.10072376.

Wegedie, K. T. (2018) Households solid waste generation and management behavior in case of Bahir Dar city, Amhara National Region State, Ethiopia. Congent Environmental Science 4:1471025. https://doi:o $\mathrm{rg} / 10.1080 / 23311843.2018 .1471025$.

Wortman, S. E., Holmes, A. A., Miernicki, E., Knoche, K. \& PiHelkow, C. M. (2017) First-season Crop Yield Response to Organic soil Amendments: A-Meta-Analysis. Agronomy Journal 109 (4), 1210 - 1217.

Zhu, Q., Ozores-Hampton, M., Li, Y., Liu, G. \& Mylavarapu, R.S. (2017) Effect of Phosphorus rates on Growth, Yield and Postharvest Quality of Tomato in a Calcareous Soil. HortScience 52 (10), 1406 - 1412. DOI: https://doi. org/10.21273/HORTSCI12192-17. 